\title{
Op die spoor van die verlede
} . 
As ek een puntenerige stukkie kritiek ten opsigte van die omslagontwerp mag opper: Die lae-resolusie grafika wat gebruik is - veral merkbaar in die gepiekseleerde rande van die bruinpapier - kan die boek gou goedkoop laat lyk. Dit sal jammer wees, want die verhale sélf is dit allermins.

Op bl. 66 kry ons dan 'n verduideliking van die Kleeinterteks: Die titel van die Fransina-siklus is daardeur geïnspireer, en meer spesifiek deur 'n vertaalde aanhaling van 'n passasie daaroor uit Walter Benjamin se Über den Begriff der Geschichte (1940) wat op sy beurt in die digbundel Veelvuldige gebruike vir huishoudelike toestelle van Andries Bezuidenhout (2014) teruggevind word. Ek haal kortliks aan:

Waar iets vir ons soos die ketting van opeenvolgende gebeure lyk, sien hy [die engel-figuur in die skildery] 'n enkele katastrofe wat onophoudelik soos wrakstukke voor sy voete neergesmyt word. (bl. 66)
Hierdie aanhaling verwoord myns insiens die bundeltema onverbeterlik. Die lewe ontplooi nie noodwendig as 'n netjiese, samehangende storie of 'plot' nie. Dit is in werklikheid meer soos die opeenstapeling van wrakstukke voor ons voete: 'n onophoudelike stroom grepe, gebeurtenisse en herinneringe. Dikwels onthutsend. Soms ontroerend. Meestal onvoorspelbaar. Soos die verhale in Tweespoor.

Juis dáárom is die kortverhaalgenre miskien so 'n geskikte voertuig waarmee ons die menslike kondisie kan verken en - soos Tilla en Fransina - op die spoor van die verlede kan teruggaan.

\section{Literatuurverwysings}

Bezuidenhout, A., 2014, Veelvuldige gebruike vir huishoudelike toestelle, Protea Boekhuis, Pretoria.

Botes, N. \& Cochrane, N., 2011, 'Generiese merkers in die kortverhaalsiklus, Deel 1, Teoretiese uitgangspunte', LitNet Akademies 8(2), 112-151. 